\title{
Why did Lord Balfour back the Balfour Declaration?
}

Philip Alexander ${ }^{1, *}$

How to cite: Alexander, P. 'Why did Lord Balfour back the Balfour Declaration?' Jewish Historical Studies, 2017, 49(1): 10, pp. 188-214. DOI:

https://doi.org/10.14324/111.444.jhs.2017v49.050.

Published: 30 March 2018

\section{Copyright:}

(c) 2017, The Author(s). This is an Open Access article distributed under the terms of the Creative Commons Attribution License (CC-BY) $4.0 \mathrm{https}: / /$ creativecommons.org/licenses/by/4.0/, which permits unrestricted use, distribution and reproduction in any medium, provided the original author and source are credited $\bullet$ https://doi.org/10.14324/111.444.jhs.2017v49.050.

\section{Open Access:}

Jewish Historical Studies is a peer-reviewed open access journal. 


\section{Why did Lord Balfour back the Balfour Declaration?*}

\section{PHILIP ALEXANDER}

In early November 1917 Lord Lionel Walter Rothschild received at his home at number 148 Piccadilly, London, a letter from Lord Arthur James Balfour, a letter which famously stated that "His Majesty's Government view with favour the establishment in Palestine of a national home for the Jewish people." This short missive was the culmination of months of behind-thescenes diplomacy by leading Zionists, and had undergone a number of redraftings by various hands before it reached its final form. Balfour was by no means the only one involved: it was an official letter that expressed the views of the British government of the day, but he signed it as Foreign Secretary, and it has gone down in history with his name attached - "The Balfour Declaration". ${ }^{1}$

The importance of this "scrap of paper" can hardly be exaggerated. It is a rare example of a decisive turning-point in history, a turning-point we can precisely date. ${ }^{2}$ It was a triumph for Weizmann and the Zionists.

I The document was a letter, but its central section, enclosed in speech-marks, is called within the letter itself a "declaration" "I should be grateful if you would bring this declaration to the knowledge of the Zionist Federation"), and this description was rapidly taken up in the contemporary press, but generally in the form "the British Declaration" or the "Declaration of the Cabinet". See the documents quoted in Nahum Sokolow, History of Zionism 1600-1918, 2 vols. (London: Longmans, Green and Co., I919), 2: 83-99, II3-16. It is not clear to me when the expression "Balfour Declaration" became widespread.

2 While we should be cautious about seeing "turning points" in history, an argument can be made in the case of the Balfour Declaration, in that it is the first link in a chain of events that culminated in the Declaration of the State of Israel on I4 May 1948. It was written into the Palestine Mandate (see esp. the preamble, and Articles 2, 4, 6, and II), which then formed the framework of such later instruments as the Peel Commission Report of July 1937, the White Paper of May 1939, the United Nations General Assembly Resolution I8I, November 1947, and finally the Declaration of Independence. The Mandate would not have been cast in the terms in which it was cast, favourable to Zionism, but for the Balfour Declaration. It would be a mistake, however, to see the Declaration

${ }^{\star}$ This is the edited text of the Presidential Lecture given to the Jewish Historical Society of England on 9 November 2017 at University College London, to mark the centenary of the Balfour Declaration. I have retained the spoken word, and the colloquialisms that went with it. The footnotes are not exhaustive but, I hope, sufficient to track down the sources. 


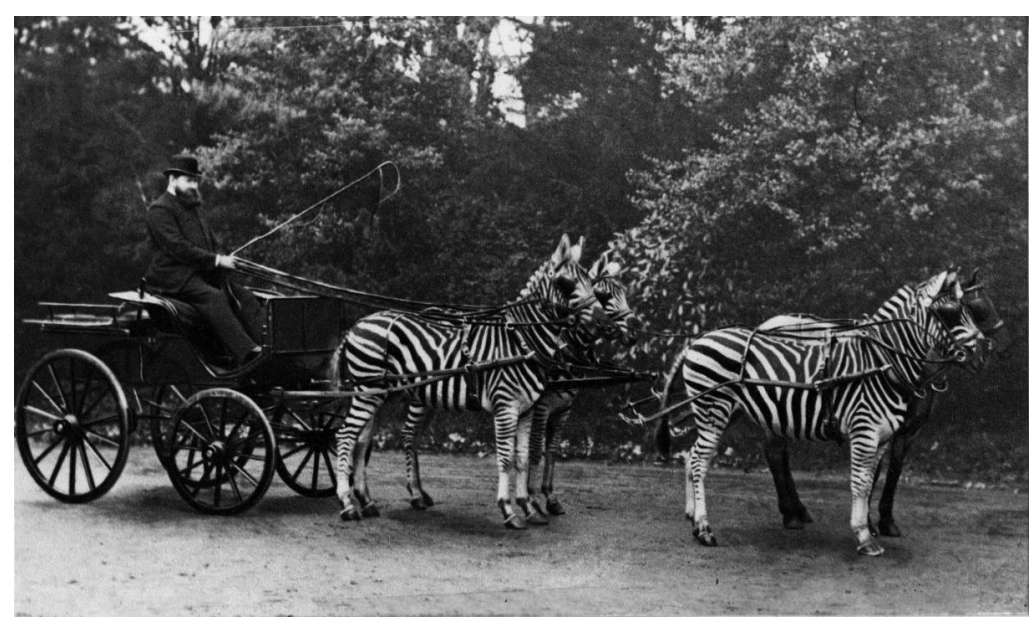

The Honourable Walter Rothschild, Picture Magazine, I895. Photograph

J. T. Newman, courtesy of Natural History Museum Images, no. 2047

A great power had gone public with its support for the creation of a Jewish homeland in Palestine-supportwhich Herzl had argued was crucial for the realization of a Jewish state, support which he had striven unsuccessfully to achieve. And, equally importantly, Britain proved able and willing to do something practical about it. The Declaration was issued as the British forces under Allenby were closing in on Jerusalem, and it formed the framework of British policy in Palestine in the immediate aftermath of his victory. Moreover, Britain saw to it that the Declaration was written into the terms of the Mandate that the League of Nations gave it to administer the region, which came into effect on 29 September 1923. There was pushback against this pro-Zionism both in Whitehall and in Palestine. Arab forces under Faisal and Lawrence had made an important contribution to the defeat of the Ottomans, and Britain had bought Arab support by promising that there would be an independent Arab state in the Middle East. The importance of oil was already well understood, and influential

of Independence as the inevitable outcome of the Balfour Declaration: the latter was a necessary but not a sufficient condition for the former. The Declaration was worded in studiedly vague terms; "a national home" was capable of both statist and non-statist interpretations. The Peel Commission Report talked clearly of two states, as did UN Resolution I8r. The 1939 White Paper categorically denied that statehood was envisaged by the Declaration, and offered Jews something that fell far short of it. Both views can be seen as legitimate parsings of the original Declaration. For the general political and historical background see D. K. Fieldhouse, Western Imperialism in the Middle East 1914-1958 (Oxford: Oxford University Press, 2006). 
voices in London argued that Britain's interests would be better served by courting the Arabs and supporting their national aspirations than by supporting the Jews. From the mid-rg2os onwards the Arabs in Palestine began to mobilize ever more assertively to oppose Zionist encroachment. And the Zionists after the Second World War ended up fighting the British, but I think few would question that the high tide of British pro-Zionism, running from the Balfour Declaration in 1917 to end of the 1920s, was crucial in embedding the Zionist enterprise in Palestine, and in giving it an international legitimacy which could not easily be revoked. Not surprisingly, it forms a key element in the legal case for independence made in the Declaration of the State of Israel in 1948: "This right [i.e. the right to independence] was recognized in the Balfour Declaration of the 2nd November, I9I7, and re-affirmed in the Mandate of the League of Nations which, in particular, gave international sanction to the historic connection between the Jewish people and Eretz-Israel and to the right of the Jewish people to rebuild its National Home." The Balfour Declaration and the Mandate are two of the pillars on which the case rests, and neither would have happened without the intervention of the British government.

All this is well known and has been written about at length by others more qualified than I. What I am interested in here is why leading figures in the British government - especially Arthur James Balfour - embraced Zionism in the early twentieth century. I am particularly interested in how far they may have been motivated by religious belief or, at least, to put it more vaguely, by religious sentiment. As a historian I have become increasingly dissatisfied by the systematic downplaying of religious motivation in academic historiography from the period after the Second World War. A kind of Marxist or sub-Marxist mindset prevails. The tendency is to play up social, economic, and political factors. Even when the actors are manifestly religious people, even when they give religious reasons for their actions, these are treated as a smoke-screen, or a rationalization for more basic social, economic, and political causes, for self-serving power-plays. Ferret these out, and you can forget the rest. ${ }^{3}$

3 I am not denying that social, political, and economic factors play an important part. Rather, I am challenging a reductionist historiography that sees them as the only factors in play. Historians who imbibe the secular ethos of modern academic historiography find it difficult to understand religious worldviews. They have no sympathy for them, no insight into them, and so prefer to talk about other things. They find it hard to believe that someone so manifestly sophisticated as Balfour, a philosopher of some standing, would not have outgrown the simple evangelical piety of his upbringing. 
In keeping with this trend many historians have stressed the Realpolitik dimensions of British support for the Balfour Declaration. The Declaration, it is argued, emerged from a particular analysis by British policy-makers of British interests in the Middle East. By the late nineteenth century the Middle East had become politically unstable. There were many factors there that the British had to keep in view, not least the relationship of the region to India, the jewel in the imperial crown. Since the opening of the Suez Canal on I7 November I869, the Middle East had become the gateway to India, so who controlled the lands adjacent to the canal, and what happened there, was of vital importance. It had long been obvious that the Ottoman Empire - the famous "Sick man of Europe" - would eventually collapse. The burning question was what would succeed it. To the alarm of Britain and France, Russia was keen to extend her influence into the Levant, and the general thrust of British foreign policy was aimed at preventing that happening. Initially, Britain supported attempts to prop up and reform the Ottoman regime, but when it became clear that these were not going to work, the problem became how she could shape the post-Ottoman world to suit her own ends. Balfour and others took the view that if the Zionists were allowed to build up a Jewish "state", with British support and encouragement, they would be reliable allies in the region.

This was certainly a line of argument that was put to them by Weizmann and others. In fact, broadly speaking, it goes back to Herzl's Der Judenstaat (I896), in which he claimed that a revived Jewish state in Palestine could form for (Christian) Europe "an integral part of its defensive wall in Asia ... an outpost of civilization against barbarism" (by which, presumably, he meant Islam). ${ }^{4}$ This can be seen as a pretty shrewd prediction of the geo-political role that Israel has come to play - a bridgehead of Western interests and values in the Arab world - and because of this it is easy now to miss how irrational was Britain's backing of the Zionists in I9I7. As has often been pointed out, Zionism in I9I7 was a small nationalist movement, insignificant in the great scheme of things. At that time it did not have strong supporteven in the Jewish world. Some of its fiercestopponents were prominent British Jews, and one of the most outspoken was the one Jew in the cabinet-Edwin Montagu, Secretary of State for India. The Declaration was nearly scuppered by Jewish opposition. True, the Zionist movement

4 "Für Europa würden wir dort ein Stück des Walles gegen Asien bilden, wir würden den Vorpostendienst der Kultur gegen die Barbarei besorgen", www.literaturdownload. at/pdf/Theodor_Herzl_-_Der_Judenstaat, I3-I4, accessed 26 Nov. 2017. 
was ably led, and had gained some access to the corridors of power in Whitehall. Balfour seems to have formed genuinely cordial relationships with Weizmann and other Zionists, such as Nahum Sokolow, and to have rated their abilities highly. Nevertheless, support for the Zionists in 1917 on Realpolitik grounds alone does not make much sense. Hence some have argued that additional factors must have been in play.

What might they have been? Two further possibilities have been canvassed. The first is that Balfour and others in the British political establishment over-estimated Jewish influence and power. Jewish influence was a trope of European antisemitism. It was classically articulated in the Protocols of the Elders of Zion, first published in Russia in 1903 , which claimed there was a secret Jewish conspiracy to dominate the world. The extent to which elements of this were a malicious parody of Herzl's Judenstaat, and the Zionist Congresses were the "reality" behind the alleged meetings of the Elders of Zion, is well known. I am not suggesting that Balfour read the Protocols, and was swayed by them: they did not become widely known in the English-speaking world till the I920s, and were not debunked as a forgery till the famous Times article of I92I, well after Balfour had become a Zionist. ${ }^{5}$ But the idea of Jewish influence was not invented by the Protocols. It was, as I have noted, a widespread trope of nineteenth-century antisemitism, and there is a certain plausibility in the suggestion that Balfour, Lloyd George, and Churchill may have, to some degree, bought into it. There is evidence to suggest that Balfour had for some time over-estimated the influence of Zionism in the Jewish community, and Weizmann played a blinder in implying that he spoke for "millions of Jews". ${ }^{6}$ By backing Zionism the British government may have

5 See the classic study by Norman Cohn, Warrant for Genocide: The Myth of the Jewish World-Conspiracy and the Protocols of the Elders ofZion (New York: Harper \& Row, I966).

6 See Weizmann's account of his meeting with Balfour in Manchester in January I906: "He [Balfour] leaned back, continued to stare at me, and said two things which I remember vividly. The first was 'Are there many Jews who think like you?' I answered 'I believe I speak the mind of millions of Jews whom you will never see and who cannot speak for themselves, but with whom I could pave the streets of the country I come from.' To this he said 'If that is so, you will one day be a force.' Shortly before I withdrew, Balfour said: 'It is curious, the Jews I meet are quite different.' I answered 'Mr Balfour, you meet the wrong kind of Jews'"; Chaim Weizmann, Trial and Error (London: Hamish Hamilton, I949), I44. Weizmann is the only source for what was said at this meeting, so we should treat what he says with a little caution. The story doubtless improved with the telling. Blanche E. C. Dugdale's account in her biography of her uncle also relies on Weizmann, whom she came to know well: Arthur James Balfour, 2 vols. (London: Hutchinson, 1936), I: $433-6$. 
hoped to influence Russian Jewry to act as a counterweight to Bolshevism, and so keep Russia in the war, or American Jewry to bolster support for the war in the United States, which came in on the Allied side only on 2 April I9I7.

An alternative suggestion (which is not incompatible with any of the foregoing) is that a crucial ingredient in Balfour's Zionism was his Christian belief or, to put it a little more subtly, his Christian formation. The most persuasive advocate of this thesis is the Canadian historian Donald Lewis in his 2010 monograph, The Origins of Christian Zionism, but it has been espoused by a number of other scholars as well. ${ }^{7}$ Actually, the basic idea is not new. In I917, as Publication No. I of the British Palestine Committee, a pamphlet by A. M. Hyamson appeared with the title British Projects for the Restoration of the Jews, which traced British support for a Jewish return to Palestine back to the sixteenth century and even, improbably, earlier. ${ }^{8}$ I have not been able to determine yet whether this appeared before or after the Declaration went public, but it was clearly linked to it. Hyamson wanted to show that support for the restoration of the Jewish people had in this country a long and honourable pedigree. A similar case was made at greater length by Sokolow in his magisterial History ofZionism 1600-1918, which appeared in I9I9 with an introduction by Balfour. ${ }^{9} \mathrm{~A}$ significant part of this massive study is taken up with tracing the history of Christian Philosemitism and Restorationism in Britain. It presents the Balfour Declaration as the culmination of a long process that had gone on in the Christian world. This perspective was largely lost in later Zionist historiography. For example, it is totally - indeed startlingly - absent from such a standard textbook as David Vital's The Origins of Zionism, published in 1975 and reprinted several times since. ${ }^{10}$ The new emphasis in some quarters on the contribution of Christian Zionism is not new, but the restatement of an older position.

My purpose in the present article is to consider whether there is evidence that Christian Zionism was indeed a significant factor in

7 Donald M. Lewis, The Origins of Christian Zionism: Lord Shaftesbury and Evangelical Support for a Jewish Homeland (Cambridge: Cambridge University Press, 2010). See also Franz Kobler, The Vision was There: A History of the British Movement for the Restoration of the Jews to Palestine (London: Lincolns-Prager, 1956); Robert O. Smith, More Desired than our owne Salvation: The Roots of Christian Zionism (Oxford: Oxford University Press, 2013).

8 Albert M. Hyamson, British Projects for the Restoration of the Jews (London: British Palestine Committee, Publication No. I, I917).

9 Sokolow, History ofZionism.

Io David Vital, The Origins ofZionism (Oxford: Clarendon Press, I975, repr. 1980, 200I). 
Balfour's support for the Balfour Declaration. That it might have been, I find perfectly credible. And here I have to declare a personal interest. I was brought up in Christian Zionist circles in Northern Ireland, and I sometimes, in moments of reflection, wonder to what extent this nudged me towards Jewish studies, and support of Israel. I am prepared to believe that it did. I am intrigued by the possibility that a somewhat similar religious formation to my own may have lain behind Balfour's support for the Balfour Declaration. Introspection, self-interrogation may be able to oil the wheels of my inquiry.

Now, there can be no doubt that by Balfour's time the idea that the Jews would return to their ancient homeland at the end of history was an article of faith for many Christians, particularly in Britain. This belief is often nowadays referred to as Christian Zionism. The definition of Christian Zionism is contested. Some argue that it is anachronistic to use it before the rise of Jewish Zionism and prefer to speak ofChristian Restorationism, or even more vaguely of Christian Judaeo-centrism. But this is too nice, and runs the risk of denying the obvious, namely that there are clear links - conceptually and historically - between Christian Zionism and Jewish Zionism. While acknowledging that there are problems, I will use Christian Zionism and Restorationism interchangeably to denote a Christian belief that biblical prophecy foresees the reconstitution of a Jewish state in the Holy Land as a precondition for the second coming of Christ.

The origins of this idea can be traced back to Elizabethan England. Indeed, and this is a point to note, it seems to be a thoroughly English phenomenon. Its earliest exponent was Thomas Brightman (1562-I607) in his influential work on biblical prophecy Apocalypsis Apocalypseos, first published posthumously in r6o9. ${ }^{11}$ It was taken up by Sir Henry Finch in The World's Great Restauration, or Calling of the Jews, and with them of all Nations and Kingdoms of the Earth to the Faith of Christ, published in I62I. ${ }^{12}$ Why the idea should have popped up in England at this time has been the subject

II Thomas Brightman, Apocalypsis Apocalypseos (Frankfurt, I6o9, repr. I6I2, I618). An English translation was published in Amsterdam in I615, reprinted in I644. See Andrew Crome, The Restoration of the Jews: Early Modern Hermeneutics, Eschatology, and National Identity in the Works of Thomas Brightman (Cham, Switzerland: Springer 20I4); see also Richard Bauckham, Tudor Apocalypse: Sixteenth Century Apocalypticism, Millenarianism, and the English Reformation (Oxford: Sutton Courtenay Press, I978).

I2 See Mel Scult, Millennial Expectations and Jewish Liberties: A Study of the Efforts to Convert Jews in Britain, up to the Mid-Nineteenth Century (Leiden: Brill, I978), I9-20. 
of much debate. Some argue that it reflects the disturbed and volatile conditions of the sixteenth and seventeenth centuries in England. This follows the thesis classically expounded by Norman Cohn in The Pursuit of the Millennium that interest in the end times coincides with periods of great political and social upheaval. ${ }^{13}$ There may be an element of truth in this but it ignores a more obvious and direct theological explanation, that the idea grew out of the new emphasis on the literal, as opposed to the allegorical or figurative, sense of Scripture promoted by the Protestant Reformers. Since antiquity the standard Christian view of the prophecies in the Hebrew Bible predicting the restoration of Israel was that they had been, or would be, fulfilled spiritually in the Church - the New Israel. But for Brightman and others, some of these prophecies were so concrete and so precise that it would be a travesty not to look for their literal fulfilment. And so they began to devise prophetic schemes in which the return of the Jews to the Holy Land and their political restoration formed an integral part. $^{14}$

Restorationism gained considerable traction among the Puritans in the seventeenth century. Itwas espoused by such giants of the study of prophecy as Joseph Mede (I586-I639) and it appears in book after book after book, particularly in the I650s, when the readmission of the Jews to England was a hot topic of debate. At this time it intersected with Jewish Restorationism as represented by Menasseh Ben Israel (I604-I657). ${ }^{15}$ It is claimed by Lewis and others that Restorationist fervour died back in the eighteenth century in England, but I am not so sure. I detect here the hidden hand of Cohn's equation of apocalypticism and political upheaval. This is what, on Cohn's theory, you would predict. The sound and fury of the Tudor and Stuart eras certainly ebbed after 1689 , but it is still possible to find many expressions of Restorationism in the eighteenth century, particularly around the time of the "Jew Bill" of $1753 \cdot{ }^{16}$ It had some high-profile advocates, including

I3 Norman Cohn, The Pursuit of the Millennium (I957, rev. and expanded New York: Oxford University Press, 1970).

I4 Andrew Crome, “'The Proper and Natural Meaning of the Prophets': The Hermeneutic Roots of Judeo-centric Eschatology”, Renaissance Studies, 24, no. 5 (2010): 725-4I.

I5 See Sina Rauschenbach, "Christian Readings of Menasseh ben Israel: Translation and Retranslation in the Early Modern World," in The Jew as Legitimation: Jewish-Gentile Relations beyond Antisemitism and Philosemitism, ed. David Wertheim (Basingstoke: Palgrave Macmillan, 2017), 63-8I.

I6 Andrew Crome, "The 1753 'Jew Bill' Controversy: Jewish Restoration to Palestine, Biblical Prophecy, and English National Identity," English Historical Review, I30, no. 547 (2015): $1449-78$. 
William Whiston (I667-I752), Isaac Newton's successor in the Lucasian Chair at Cambridge, in his day a respected scientist but now better known as the translator into English of the works of Flavius Josephus. Newton himself believed it, as did the polymath Joseph Priestley (1733-I804), the discoverer of oxygen. ${ }^{17}$ It was introduced into Ireland by the controversial Bishop Robert Clayton (1695-I758), in his Dissertation on Prophecy ... with an explanation of the Revelation of St. John (1749) and Inquiry into the Time of the Coming of the Messiah and the Restoration of the Jews (I75I). ${ }^{18}$ Clayton may have sown the seeds for the dramatic flowering of Restorationism in Dublin in the first half of the following century. Its advocacy by people like Whiston, Clayton, and Priestley makes an important point. From the nineteenth century to the present day, Restorationism has been strongly associated with conservative Evangelical Christianity, and some have argued that it is intimately bound up with Evangelical identity. It is part of Evangelical DNA. But the connection is not exclusive, as Whiston, Clayton, and Priestley show. All three were rationalist and espoused forms of Christianity which were regarded as radical and, indeed, heretical in their day. The common element here is a rigorous biblical literalism. There is a streak of rationalism running through Evangelical biblical hermeneutics. Although on one level Evangelicalism reacted negatively to the Enlightenment, at the level of hermeneutics it embraced it (for Whiston

I7 The basic bibliography can be gleaned from Sokolow, History of Zionism; Kobler, The Vision was There; Scult, Millennial Expectations; Lewis, Origins of Christian Zionism; Smith, Roots ofChristian Zionism. Whiston tends to get passed over in the surveys. See e.g. his The Literal Accomplishment of Scripture Prophecies (London, I724), essay IV, "Natural Preparations for the Destruction of Antichrist; for the Revival of Primitive Christianity; and for the Restoration of the Jews, in the last Days". See also Stephen D. Snobelen, "William Whiston: Natural Philosopher, Prophet, Primitive Christian" (Ph.D. thesis, Cambridge University, 2000); Adam Shear, "William Whiston's Judeo-Christianity: Millenarianism and Christian Zionism in Early Enlightenment England", in Philosemitism in History, ed. Jonathan Karp and Adam Sutcliffe (Cambridge: Cambridge University Press, 200I), 93IIo. On Newton see Stephen D. Snobelen, “'The mystery of this restitution of all things': Isaac Newton on the Return of the Jews", in The Millenarian Turn: Millenarian Contexts of Science, Politics, and Everyday Anglo-American Life in the Seventeenth and Eighteenth Centuries, ed. James E. Force and Richard H. Popkin (Dordrecht: Kluwer, 200I), 95-II8.

I8 Robert Clayton, A Dissertation on Prophecy, Wherein the Coherence and Connexion of the Prophecies in both the Old and New Testaments are fully considered; Together with an Explanation of the Revelation of St. John (London, 1749); An Enquiry into the Time of the Coming of the Messiah and the Restoration of the Jews: in a Letter from Robert, Lord Bishop of Clogher, to an Eminent Jew (London, 175I). I chose Clayton because he tends to get left out of the surveys. See also C. D. A. Leighton, "The Enlightened Religion of Robert Clayton", Studia Hibernica, 29 (1995I997): $157-84$. 
the literal fulfilment of biblical prophecy was an important rational proof for the truth of Christianity).

All this said, it would wrong to deny that there was an upsurge of Restorationism in early nineteenth-century England, and clearly it was linked to the French Revolution and the rise of Napoleon. The British upper classes had been shaken to the core by events on the Continent and were fearful for their future. One result of this was a renewed interest in biblical prophecy, particularly in unfulfilled prophecy. This, in turn, led to a strong interest in the Jewish people. What part did the Scriptures say they would play in the future purposes of God? An important focus of this development was a series of conferences held from I826 to I830 at Albury, the country seat of Henry Drummond, not far from London. Leading lights of the new wave of prophetic study, such as Edward Irving (I792-I834) and John Nelson Darby (I800-I882), attended. At this period the movement was strikingly middle and upper-class in its social makeup, with salon Evangelicalism playing a conspicuous part in it.

The Albury Conferences transferred to the Powerscourt estate outside Dublin and were held there (from I83I to I833) under the patronage of Lady Powerscourt, Theodosia Anne Howard (1800-1836). Darby, whose family estate was at Leap Castle in County Offaly, and who had been educated at Trinity College Dublin, was the star of these meetings. ${ }^{19}$ Darby, while in Ireland, developed a version of Restorationism, known as Dispensationalism, which has proved highly influential in the twentieth and twenty-first centuries. There was an indigenous North American tradition of Restorationism, taken there by the Puritans in the seventeenth century. It was embraced by such New England luminaries as Increase Mather (I639-1723) and his son Cotton Mather (I663-I728), though the latter abandoned it late in life. But it received an enormous shot in the arm when Darbyite Dispensationalism was brought into the United States,

I9 For Darby's biography see Max S. Weremchuk, John Nelson Darby: A Biography (Neptune, NJ: Loiseaux, I992), which should be supplemented and corrected by Timothy C. F. Stunt, "Darby, John Nelson (I80o-I882)", Oxford Dictionary of National Biography (hereafter, ODNB) online (2004). For an analysis of Darby's Dispensationalism see Paul Wilkinson, For Zion's Sake: Christian Zionism and the Role ofJohn Nelson Darby (Milton Keynes: Paternoster, 2007). For the general picture see Crawford Gribben and Andrew R. Holmes, eds., Protestant Millennialism, Evangelicalism and Irish Society, 1790-2005 (Basingstoke: Palgrave Macmillan, 2004); Crawford Gribben and Timothy C. F. Stunt, eds., Protestant Millenarianism in Britain and Ireland, 1800-1880 (Carlisle: Paternoster Press, 2006); D. H. Akenson, Discovering the End of Time: Irish Evangelicals in the Age of Daniel O'Connell (Montreal: McGill-Queen's University Press, 2016). 
in part by Darby himself, who had distinguished American relatives and undertook several speaking tours in the country. It was popularized by Cyrus Scofield (I843-I92I) in his famous Reference Bible, published by Oxford University Press (1909, revised 1917), arguably the most influential edition of the English Bible ever published, from which Oxford University Press has made a fortune. It is still in print. Dispensationalism was adopted as an article of faith by Dallas Theological Seminary (founded I924), the most important conservative seminary in the States. It got into the bloodstream of conservative Evangelical theology, and now forms the ideological underpinnings of the powerful Christian Zionist movement in North America. These conservative, Evangelical Christians passionately believe that the founding of the State of Israel in 1948 is the fulfilment of biblical prophecy, and a clear sign that the Second Coming of Christ is at hand. And they believe that Christians have a duty to support Israel and help her achieve her God-given destiny in whatever way they can. ${ }^{20}$

This sketch of the history of Christian Zionism over the past four hundred years raises interesting questions for historians of Judaism. It represents an aspect of the relationship between Jews and Christians which is only now beginning to get the attention it deserves. Historians have rightly highlighted the fact that Christian Zionists continued to believe that the Jewish people constituted a nation, and that they would in the future enjoy a glorious national revival in their old homeland. This belief ran counter to classic Christian theology which held that Israel as a nation had come to an end with the destruction of the Temple in $70 \mathrm{CE}$. That catastrophe was God's judgment on the Jews - a clear sign that, as a nation, they no longer had a role to play in the purposes of God. But equally it ran counter to powerful trends in Jewish thought in the nineteenth century. These found expression not only in Reform, which saw Judaism as having transcended its national past, ${ }^{21}$ but also in more orthodox circles as well, which were

20 Ernest R. Sandeen, The Roots of Fundamentalism: British and American Millenarianism 1800-1930 (Chicago: University of Chicago Press, repr. 2008); Yaakov Ariel, On Behalf of Israel: American Fundamentalist Attitudes toward Jews, Judaism, and Zionism, 1865-1945 (Brooklyn: Carlson, I99I); Victoria Clark, Allies for Armageddon: The Rise of Christian Zionism (New Haven and London: Yale University Press, 2007); Crawford Gribben, Evangelical Millennialism in the Trans-Atlantic World, 1500-2000 (Basingstoke: Palgrave Macmillan, 20II). For an attempt to articulate a "New Christian Zionism" see Gerald R. McDermott, ed., The New Christian Zionism: Fresh Perspectives on Israel and the Land (Downers Grove, IL: InterVarsity Press, 2016).

2I See e.g. Article I of the Principles of the Philadelphia Conference of I869: "The 
worried about "forcing the redemption" (I shall come back to this idea in a moment), and felt there was an uncomfortable tension between agitating for emancipation on the one hand and advocating the restoration of a Jewish state on the other. Modern political Zionism had an uphill struggle in the early years, and was opposed by many, from all shades of opinion, within the Jewish world. Leading Zionists welcomed the support of Christian Zionists, some of whom attended the Zionist congresses, from Basle onwards. One thinks here of Herzl's lieutenant, the flamboyant and eccentric Reverend William Henry Hechler (I845-I93I).

It is important to grasp that this Christian idea that Jews continued to constitute a nation goes all the way back to Brightman, and that the national dimension of Judaism is fundamental to Christian Zionism in all its forms. James Renton in his reading of British motives for backing Zionism, The Zionist Masquerade: The Birth of the Anglo-Zionist Alliance 19141918 (2007), makes a carefully argued case that Balfour and others in the British establishment backed Zionism because they bought into late nineteenth-century theories of race and nationalism:

The belief in Whitehall that Jewry was a nation derived from a general imagining of ethnic groups as cohesive, racial entities that were driven by a profound national consciousness. Fundamentally influenced by the racial nationalist thought that came into prominence in British and European culture in the late nineteenth century, the Government officials and politicians behind the Balfour Declaration viewed identity and social relations through this prism. It was for this reason, in the final assessment, that Zionism, as a mirror image of the policy-makers' own beliefs and identity, was accepted and embraced as representing the authentic desires of world Jewry. ${ }^{22}$

Messianic aim of Israel is not the restoration of the old Jewish state under a descendant of David, involving a second separation from the nations of the earth, but the union of all men as children of God in the confession of the unity of God, so as to realize the unity of all rational creatures and their call to moral sanctification." And Article 5 of the Pittsburgh Platform of 1885 : "We consider ourselves no longer a nation but a religious community, and therefore expect neither a return to Palestine, nor a sacrificial worship under the administration of the sons of Aaron, nor the restoration of any of the laws concerning the Jewish state." By the Columbus Platform of 1937 , however, a more positive attitude towards national revival had emerged: "In the rehabilitation of Palestine, the land hallowed by memories and hopes, we behold the promise of renewed life for many of our brethren. We affirm the obligation of all Jewry to aid in its upbuilding as a Jewish homeland by endeavouring to make it not only a haven of refuge for the oppressed but also a center of Jewish culture and spiritual life."

22 James Renton, The Zionist Masquerade: The Birth of the Anglo-Zionist Alliance 1914-1918 (Basingstoke: Palgrave Macmillan, 2007), 4. 
I would not deny that Balfour's views of the nationhood of the Jewish people dovetail with late nineteenth-century racial nationalist thinking. What I would challenge is the implication that this thinking was radically new, and that invoking it as a cause negates the influence of Christian Zionist ideas of Jewish nationhood, as Renton implies. Where did late nineteenth-century racial nationalist ideas come from? Arguably, one of its roots lies in early biblically based thinking on the nature of the nation and the state. It should not be forgotten that the Bible plays a role in foundation documents of European political philosophy such as Hobbes's Leviathan. Modern philosophies of the state owe much to prior theologies of the state. Israel was seen by many early modern political thinkers as the paradigm of nationhood. The French Revolution unquestionably brought about a change in our understanding of the nature of nationhood and of the state, but it does not mark an absolute caesura in the development of political thought. People talked about nationhood before the French Revolution, and after, but there is no justification for seeing a radical discontinuity between the pre- and post-revolutionary points of view. Rather, one evolved out of the other. ${ }^{23}$

The process of secularization has to be understood in a nuanced way. Renton perceptively notes that Zionism presented to Balfour and others "a mirror image of the policy-makers' own beliefs and identity", but this "mirroring" goes all the way back to the origins of Christian Zionism. As Crome and others have argued, Christian Restorationism in Britain was intimately bound up with attempts to define a British national identity, an important element of which was the conviction that Britain was an elect nation, with a peculiar destiny in the purposes of God. ${ }^{24}$ This idea could be used to generate a sort of replacement theology: Britain has taken the place of Israel as God's Chosen People. But just as often Britain's election was seen as a secondary election. Israel remained God's primary chosen people, and would one day be restored to political sovereignty and, indeed, world domination. Britain's destiny was to facilitate that restoration, to play the Cyrus role, and to receive God's blessing for doing

23 Nationalism and national identity are a hot topic among historians. That makes it all the more imperative to avoid sweeping dogmatism. The literature is extensive but see Stewart Mews, ed., Religion and National Identity (Oxford: Blackwell, I982); Liah Greenfield, Nationalism: Five Roads to Modernity (Cambridge, MA: Harvard University Press, I992); Achsah Guibbory, Christian Identity, Jews and Israel in Seventeenth-Century England (Oxford: Oxford University Press, 2010).

24 See Crome, Restoration of the Jews, and "The 1753 'Jew Bill' Controversy". 
so. Genesis I2:I-3 was a key text. There God says to Abraham: "Go from your country and your kindred and your father's house to the land that I will show you. I will make you a great nation ... I will bless those who bless you, and the one who curses you I will curse." 25 Late nineteenthcentury racial nationalism and pre-French Revolution Christian Zionist ideas of the nationhood of Israel are not radically incompatible. Balfour could have assimilated one to the other. He could have been influenced by both. It is not a simple question of either/or.

There was also another aspect to Christian Zionism in which it anticipated later Jewish Political Zionism: some Christian Zionists were prepared to take practical steps to promote a return of the Jews to their ancient homeland. Religious Zionism, the Zionism of the Jewish Prayer Book, is non-activist. You may pray with great fervour daily in the Amidah for the return to Zion, but you are not supposed to do anything practical and political about it. You have to wait on God. It is a cardinal sin to "force the redemption". ${ }^{26}$ Non-activism was also a feature of Dispensationalism: Darby was totally opposed to any Christian involvement in politics. The Christian's duty was to withdraw from the world and await God's judgment (however, Darbyite Dispensationalism has become intensely political in the United States). But other forms of Christian Zionism were prepared to contemplate, and even to take, concrete action to facilitate the return.

Christian Zionist activism found expression in a variety of ways, some of which were, frankly, deranged, as in the case of Richard Brothers (I757I824), the self-styled "Prince and Prophet of the Hebrews" and "Nephew of the Almighty", who believed that the British were the Lost Ten Tribes, and that he had been called by God to lead them back to Palestine and re-establish there the state of Israel. Brothers's prophecies were widely disseminated, and his ideas caused quite a stir. The authorities, alarmed by the agitation he was causing, had him medically examined and confined as criminally insane. ${ }^{27}$ Brothers recalls in some ways Shabbetai

25 See also William Haller, Foxe's Book of Martyrs and the Elect Nation (London: Jonathan Cape, 1963); Anthony D. Smith, Chosen Peoples (Oxford: Oxford University Press, 2003); Todd Gitlin and Liel Leibovitz, The Chosen Peoples: America, Israel, and the Ordeals of Divine Election (New York: Simon and Schuster, 20Io).

26 See Aviezer Ravitzky, Messianism, Zionism, and Jewish Religious Radicalism (Chicago and London: University of Chicago Press, 1996), esp. chs. I and 2.

27 See Timothy F. C. Stunt, "Richard Brothers", ODNB (2004), also Cecil Roth, The Nephew of the Almighty: An Experimental Account of the Life and Aftermath of Richard Brothers R.N. 
Tzevi (I626-I676), who would probably have suffered a similar fate had he lived in England.

A similar fate befell another activist Restorationist of the same period, the Irish heiress Marianne Nevill. Miss Nevill was different from Brothers - a genteel, unmarried lady of considerable wealth. The steps she took were much more practical, and in uncanny ways anticipate by some sixty years the programme outlined by Herzl in Der Judenstaat, the manifesto of Political Zionism. She was not the first Christian to embrace activism, but her form of it was astonishingly practical. Hitherto, Christian Zionist activism had gone little beyond proposing that the Britain should use her mighty navy to transport the Jews to Palestine, set them up there, then leave them to their own devices. But Miss Nevill approached the whole problem in a more systematic, business-like, hard-headed way. She tried to make overtures to Mehmet Ali of Egypt, who had broken away from the Ottoman Empire, to interest him in her plan for Jewish restoration. She tried to establish an organization that would finance and manage the return, and, through Lady Judith, to get Sir Moses Montefiore involved. She studied the economic potential of the country and shrewdly noted how it could be made economically viable. She happily planned its infrastructure and currency - all this from her elegant Georgian terrace at number 2 Mountjoy Square, Dublin! In the end, in 1837 , she too was declared insane by an Irish court (her trial was a cause célèbre widely reported in the Irish and English press): she lost control of her estate and was more or less confined to her house. What triggered this action was alarm on the part of her family that she was about to throw away her fortune on a wild venture to finance the return of the Jews to their ancient homeland. ${ }^{28}$

Brothers and Nevill represent what might be called the "lunatic fringe" of activist Christian Zionism, but activism could also take more moderate forms. This can be illustrated by Richard Graves ( $1763-1829$ ), a contemporary of Brothers and Nevill. Graves was a highly respected member of the Anglo-Irish establishment. In I8I4 he became Dean

(London: Edward Goldstone, 1933); Clarke Garrett, Respectable Folly: Millenarians and the French Revolution in France and England (Baltimore and London: Johns Hopkins University Press, 1975), 179-223; J. F. C. Harrison, The Second Coming: Popular Millenarianism, 17801850 (1979; repr. Abingdon and New York: Routledge, 2012), ch. 4.

28 See The Speech of the Rt Hon. Francis Blackburne on behalf of Miss Nevill, in the Court of Queen's Bench, on the 10th ofJanuary, 1838 , and studiously suppressed in the published account of the trial, as reported by a barrister (Dublin: James Charles for the Friends of Miss Nevill, I843); also my "Christian Restorationism in Ireland in the Early Nineteenth Century: The Strange Case of Miss Marianne Nevill”, Jewish Historical Studies: Transactions of the Jewish Historical Society of England, 47 (2015): 3I-47. 
of Ardagh, and in I8rg Regius Professor of Divinity at Trinity College Dublin. ${ }^{29}$ It would be hard to imagine anyone more staid and sober. Graves's scholarly reputation was established by his two-volume magnum opus, The Divine Origin of the Jewish Religion, proved from internal evidence of the last four Books of the Pentateuch. ${ }^{30}$ This was based on the prestigious Donnellan Lectures at Trinity Dublin for 1797 and I8or. Graves devotes his final chapter to "The Future Conversion and Restoration of the Jews". He not only argues that biblical prophecy clearly foretells that the Jewish people will return to their ancient homeland, but also, reading the signs of the times, he ventures to suggest that the return may be imminent. And he sees Britain as having an important, practical role to play in this great event. Just below the surface of his erudite text, a political programme is bubbling away. He notes that the decline of Ottoman power affords an opportunity to re-establish the Jews in Palestine, as does the relatively abandoned state of the Promised Land itself, which means it is simply crying out for settlers - a remarkable anticipation of the later Zionist trope about the "land without people for a people without land". ${ }^{31}$ Another aspect of the Jewish condition he notes as favourable to a return is the fact that many Jews are involved in commerce, few in agriculture, which makes it easier for them to pack their bags and go. And in all this there is a role for "such nations as shall be distinguished for commercial exertion and naval power" to facilitate

the accomplishment of that remarkable prophecy of Isaiah . . . which declares, when speaking of the grand restoration of the people of God, 'Surely the isles shall wait for me, and the ships of Tarshish first, to bring thy sons from afar, their silver and gold with them, unto the name of the Lord thy God, and to the Holy One of Israel, because he hath glorified thee' [Isaiah 6o:8-9] ${ }^{32}$

Graves is, of course, thinking here specifically of a role for Britain - the greatest commercial and naval power of its day - to serve the purposes

29 See B. H. Blacker and David Huddleston, "Richard Graves", ODNB (2004). I thank Timothy Stunt for an illuminating email exchange on Graves.

30 Richard Graves, The Divine Origin of the Jewish Religion, proved from the internal evidence of the last four Books of the Pentateuch, 2 vols (1807; repr. with substantial additions Dublin: Cadell \& Davies, I8I5, Ioth edn. I865), final ch., "On the Future Conversion and Restoration of the Jews".

3I The sentiment was widely expressed, in a variety of forms, in Christian Zionist writings of the nineteenth century; see e.g. Wikipedia, "A land without people for a people without land".

32 Graves, Divine Origin, 428-9. 
of God, to play the Cyrus role, and reap the harvest of divine favour as a reward.

By the 1830 s the British Restorationists were beginning to coalesce into an effective political lobby, intent on influencing British foreign policy in favour of a Jewish return to the Land. And in Anthony Ashley-Cooper, Lord Shaftesbury (I80I-I885), a man of impeccable pedigree and undoubted political influence, they found a champion. ${ }^{33}$ Shaftesbury, a noted Evangelical and member of the so-called Clapham Sect, was a dyed-in-thewool Restorationist, and on several occasions he pressed Palmerston to do something to promote the return of the Jews to Palestine. On I7 August I840, The Times, in a contribution under the title "Syria - Restoration of the Jews", reported that "a nobleman of the opposition" (almost certainly Shaftesbury) had been making enquiries along the following lines: (I) What did the Jews think of the proposed restoration to the Holy Land? (2) Would rich Jews go to Palestine and invest their capital in agriculture? (3) When would they be ready to go? (4) Would they go at their own expense, requiring nothing more than assurances of safety to life and property? (5) Would they consent to live under the Turkish government, with their rights protected by the five European Powers?

These hopes were by no means unrealistic, because the leading Jew in England at the time, Moses Montefiore (1784-1885), ever since his first visit to Palestine in 1827 , had shown a commitment to building up and supporting Jewish settlement there. Here was an obvious Jewish partner who could lead the way from the Jewish side in the realization of the Restorationists' dream. Three years later the Colonial Times for Tuesday 23 February I84I reproduced a "Memorandum to Protestant Monarchs of Europe for the restoration of the Jews to Palestine". Again, Shaftesbury was involved, though he was not the only signatory. The memorandum laid out succinctly the biblical proofs that the Jewish people were destined to be restored to their land, and called on Protestant monarchs to assist in this divinely sanctioned process.

Nothing much came of this agitation, though it undoubtedly played a part in rousing Britain to intervene to protect Jews in the Middle East in the wake of the Damascus Blood Libel (I840). ${ }^{34}$ And Palmerston, at Shaftesbury's prompting, did establish a British Consulate in Jerusalem in 1838 , the first of the European Powers to do so, which flagged up to

33 For all that follows see Lewis, Origins ofChristian Zionism.

34 Jonathan Frankel, The Damascus Affair: Politics and the Jews in 1840 (Cambridge: Cambridge University Press, 1997). 
the Ottomans Britain's interest in the region, and specifically in the Jews living there. It also bore fruit in the curious joint British-Prussian venture of the Jerusalem Bishopric (I842).

This latter development illustrates how problematic Christian Restorationism was, and indeed remains, from a Jewish point of view. It was strongly motivated by a desire to convert the Jews and bring them into the Christian fold. The classic Restorationist view was that the return to Palestine would be accompanied by a mass conversion to Christianity, some believing that the restored Israel as a Christian state would then have a key role to play in the conversion of the rest of humanity. This is why Graves saw the founding of the London Society for Promoting Christianity amongst the Jews, of which he was an active member, as a sign that the return might be at hand. The Dispensationalists, however, held that the Jews would return to Palestine in unbelief, and this modification of the standard view has proved important, because it has allowed them to identify the present State of Israel as the beginning of the eschatological return. But even they envisage the eventual conversion of a remnant of Jews, with the rest being annihilated in the battle of Armageddon.

This conversionist impulse puts a question mark against the description of Restorationism as "philosemitic", a term applied to it from time to time. ${ }^{35}$ Restorationists certainly have warm words to say about Jews, and

35 On Philosemitism see David S. Katz, Philo-Semitism and the Readmission of the Jews to England 1603-1655 (Oxford: Clarendon Press, 1982); William D. Rubinstein and Hilary L. Rubinstein, Philosemitism: Admiration and Support in the English Speaking World for the Jews (Basingstoke: Macmillan, 1999); Tony Kushner and Nadia Valman, eds., Philosemitism, Antisemitism and 'the Jews': Perspectives from the Middle Ages to the Twentieth Century (Aldershot: Ashgate, 2004); Wertheim, Jew as Legitimation. The Jewish objections to philosemitism are forcefully put by Todd Endelman in a review of Katz, American Jewish History, 72, no. 3 (I983): 410: “The term 'Christian philo-Semitism' is something of a misnomer. Christians, to whom historians apply the term 'philo-Semitic', love Jews not as Jews but rather as peculiarly valuable potential converts to the Christian faith, whose fulfilment requires Jewish acknowledgment of Jesus as the Christ. Philo-Semitic Christian groups have championed Jewish rights and interests over the past four centuries for exclusively Christian reasons. They have opposed discrimination and denounced antisemitism because they have sought to bring Jews into closer contact with Christian society, thereby exposing them to the influence of Christian teaching and example. If they have promoted the return of the Jews to the Land of Israel, it is because the ingathering of the exiles is a critical step in the realization of their own millenarian dreams. None of these groups, as far as I know, has granted Judaism a theological legitimacy of its own, independent of future hopes for the absorption of the Jews into Christendom". This is, perhaps, a bit too black and white, and does not reflect the complexities of philosemitism (e.g. twocovenant positions and support for Jews on altruistic, moral grounds) but it captures well enough the dominant traits of the tradition. 
actually have an admirable record of defending them against antisemitic attacks, yet they still want to make them Christians, and the missions they have supported have sometimes been aggressive in their tactics, and can be accused of exerting undue pressure. Nor do they necessarily back Jewish rights. This is something that has puzzled commentators about Balfour. The backer of the Balfour Declaration was the backer of the Aliens Act of 1905 which was aimed squarely at Jewish immigration into the United Kingdom. Some see this as a case of inconsistency or maybe a change of heart, but it reveals a negative attitude that has antecedents in Restorationist thinking. Graves, for example, argues that it is important that Jews remain apart. The implication is that this is necessary so that they can play their distinctive role in history. Emancipation could lead to their assimilation and loss of identity, and so should be opposed. Graves does not draw this conclusion in so many words, but it had certainly been drawn by some Restorationists at the time of the Jew Bill in 1753 . Why grant Jews civil rights and make them citizens when they may be off soon to Palestine to found their own state? There is a long tradition of Christian exceptionalism towards Jews - a phenomenon labelled by Zygmunt Bauman "allosemitism". ${ }^{36}$ Even when they convert, they are seen in some ways as not like other converts. They have to do more to prove their sincerity. They are trophies to be flaunted before the world as a validation of the Church to which they have converted. The seriousness with which Restorationists took the need to keep Jews apart is seen in the growing trend in the I8zos to support the formation of Hebrew Christian Congregations: Jewish converts were encouraged to continue to meet as Jewish Christians and to have their own distinctive services in Hebrew. This is the real origin of the phenomenon of Messianic Judaism, and not the Joseph Rabinowitz congregation in Kishinev in the I88os, as is often claimed. ${ }^{37}$

Much more could be said on this subject but I have said enough to show that by the end of nineteenth century there was a well-entrenched and widespread belief among Christians in Britain that the Jewish people

36 Zygmunt Bauman, "Allosemitism: Premodern, Modern, Postmodern”, in Modernity, Culture and 'The Jew', ed. Bryan Cheyette and Laura Marcus (Cambridge: Polity, I998), ch. 8. The term was invented by the Polish literary critic Artur Sandauer.

37 Miss Nevill was an enthusiastic supporter of Hebrew Congregations: see Alexander, "Christian Restorationism in Ireland"; also Michael R. Darby, The Emergence of the Hebrew Christian Movement in Nineteenth-Century Britain (Leiden: Brill, 2010); Kai Kjaer-Hansen, Joseph Rabinowitz and the Messianic Movement: The Herzl of Jewish Christianity (Grand Rapids, MI: Eerdmans, 1994). 
were destined to return to their ancient homeland and restore their state, that that event might be imminent, and that Christians had a duty to do whatever they could to facilitate the return. This belief had escaped from the pulpit and the theological literature into public discourse, and there had been some notable attempts to take concrete measures to put bring it about. All this, it should be stressed again, happened well before political Zionism had raised its head in the Jewish world. The paradox is that there was potentially a more ready and receptive audience for Herzl's Zionism in the Christian world, at least in Britain, than there was in the Jewish.

It is simply inconceivable that Balfour did not know all this, but was he influenced by it? That is more problematic. Part of the problem lies with his personality. Contemporaries and biographers have all noted that in public he was undemonstrative and reserved: he played his cards close to his chest. He effected a languid, supercilious, superior air. Like Tony Blair, he did not do God - unlike Gladstone. Yet his religious formation was profoundly Christian, and the kind of Christianity that shaped him was the mainstay of Christian Zionism. He knew his Bible and, it is probably true to say, he was the most theologically literate prime minister this country has ever had, with the possible exception of Gladstone. He gave the Gifford Lectures for I9I4 on "Theism and Humanism", and for 1922-23 on "Theism and Thought". He wrote, among other things, an introduction to theology, The Foundations of Belief. ${ }^{38}$ Balfour was brought up by a pious, Evangelical mother, whose influence he acknowledges in his autobiography: his father died when he was five. ${ }^{39}$ Family prayers and Bible study were a feature of his childhood. The author of his "official" biography, his niece Blanche Dugdale, herself an ardentZionist (converted by her uncle to the cause), had no doubt that his lifelong interest in the Jews "originated in the Old Testament training of his mother, and in his Scottish upbringing." ${ }^{\prime 0}$ He worshipped in the Church of Scotland when he

38 A. J. Balfour, Theism and Humanism, being the Gifford Lectures 1914 (London: Hodder and Stoughton, I9I5); Balfour, Theism and Thought: A Study of Familiar Beliefs, being the econd series of Gifford Lectures delivered at the University of Glasgow 1922-23 (London: Hodder and Stoughton, 1924); Balfour, The Foundations of Belief: being notes introductory to the study of Theology (I895; 8th rev. edn. London: Longmans Green, I9or).

39 A. J. Balfour, Chapters of Autobiography (London: Cassell, I930), 3.

40 Dugdale, Arthur James Balfour, I: 433. Weizmann, Trial and Error, 200, 226, was of the same opinion: "Men like Balfour, Churchill, Lloyd George, were deeply religious and believed in the Bible. To them the return of the Jewish people to Palestine was a reality, so that we Zionists represented to them a great tradition for which they had enormous 
was at home at Whittinghame in East Lothian and, I imagine, from time to time attended the Church of England when he was south of the border. $\mathrm{He}$ would have sat under both Presbyterian and Anglican ministers. Restorationism was strong in both communions. As early as I839, the Church of Scotland had sent out to Palestine four of its ministers including Andrew Bonar and Murray McCheyne (both of them committed Restorationists) - to report on the condition of the Jews in Palestine, and the report which they produced went through several editions and was much discussed. ${ }^{41}$

On Lloyd George's own admission, a biblical upbringing played a crucial role also in his support for the Balfour Declaration. On Monday 25 May 1925, Philip Guedalla gave the Eighth Arthur Davis Memorial Lecture at University College London to the Jewish Historical Society of England on "Napoleon and Palestine". Israel Zangwill presided. Lloyd George gave the vote of thanks. ${ }^{42}$ In a remarkable speech he traced his "natural sympathy" for the Jewish people back to his Welsh Baptist roots, his schooling, and his Sunday school. The passage is famous, but is worth quoting again:

You must remember we had been trained even more in Hebrew history than in the history of our own country. ... I could tell you all the kings of Israel. But I doubt whether I could have named half a dozen of the kings of England, and not more of the kings of Wales. ... On five days a week in the day school, and on Sundays in our Sunday schools, we were thoroughly trained in the history of the Hebrews. We used to recite great passages from the prophets and the Psalms. We were thoroughly imbued with the history of your race in the days of its greatest glory, when it founded that great literature which will echo to the last days of this old world, influencing, moulding, fashioning human character, inspiring and sustaining human motive, for not only Jews, but Gentiles as well. We absorbed it and made it part of the best of the Gentile character.

Historians have rightly taken this statement with a pinch of salt, just as they have shown understandable scepticism about Lloyd George's claim

respect. . . . Those British statesmen of the old school, I have said, were genuinely religious. They understood as a reality the concept of the return. It appealed to their tradition and their faith".

4I Andrew Bonar and Murray McCheyne, Narrative of a Visit to the Holy Land and Mission of Inquiry to the Jews from the Church of Scotland in 1839 (I842; 3rd edn. Edinburgh: William Whyte, I849).

42 Philip Guedalla, Napoleon and Palestine, with a Foreword by Israel Zangwill and an Afterword by David Lloyd George (London: Allen \& Unwin, I925). 
that it was acetone that converted him to Zionism. It became a kind of "shtick" which he trotted out when occasion demanded. He was playing to the gallery. Nevertheless, it would be wrong to dismiss it out of hand. Lloyd George's background was Welsh Baptist, whereas Balfour's was Evangelical Presbyterian, but in evangelical ethos and attitudes towards the Jews they were effectively the same, though Balfour would have shuddered to wear his heart on his sleeve like the more flamboyant and emotional Welshman.

Balfour on a number of occasions did explain his reasons for supporting the famous Declaration. Blanche Dugdale singles out one of these as being particularly enlightening. It is a speech he made in the House of Lords in 1922 when Lord Islington argued against Britain's acceptance of the League of Nations Mandate for Palestine. "I hold", said Balfour,

that from a purely material point of view the policy we initiated is likely to prove a successful policy. But we have never pretended - certainly I have never pretended - that it was purely from these materialistic considerations that the Declaration of November 1917 originally sprang. I regard this not as a solution, but as a partial solution, of the great and abiding Jewish problem ... I do not deny that this is an adventure. Are we never to have adventures? Are we never to try new experiments? ... Surely, it is in order that we may send a message to every land where the Jewish race has been scattered, a message that will tell them that Christendom is not oblivious of their faith, is not unmindful of the service they have rendered to the great religions of the world, and most of all to the religion that the majority of Your Lordships' house profess, and that we desire to the best of our ability to give them that opportunity of developing in peace and quietness under British rule, those great gifts which hitherto they have been compelled to bring to fruition in countries that know not their language and belong not to their race? That is the ideal which I desire to see accomplished, that is the aim which lay at the root of the policy I am trying to defend; and though it is defensible indeed on every ground, that is the ground which chiefly moves me. ${ }^{43}$

Every line of this careful statement deserves careful parsing. Note (I) its idealism, its rejection of Realpolitik. It was not "materialistic considerations" that motivated him to back Jewish nationalism.

Note (2) the reference to Zionism as "a solution, a partial solution of the

43 Dugdale, Arthur James Balfour, 2: 216-I7, quoting Hansard. Also useful is Balfour's "Introduction" to Sokolow, History of Zionism, I: xxix-xxxiv; Balfour, Speeches on Zionism, ed. Israel Cohen (London: Arrowsmith, 1928). 
great and abiding Jewish question." One immediately thinks here of the argument of Herzl's Der Judenstaat, that Christian Europe will always find it impossible to assimilate Jews. Antisemitism is well-nigh ineradicable. The only solution is to remove the Jews to their own homeland. This will diminish the problem of their presence in Europe, and at the same time normalize relationships between the Christian majority and those left behind. It is tempting to suppose that Balfour had read Der Judenstaat, but actually the idea that the restoration of the Jews to Palestine was a solution to antisemitism was a well-known trope of Christian Zionism. Christian Zionists were arguing this well before Herzl ever put pen to paper.

Note (3) the hints of exceptionalism in the romantic, idealized picture of innate Jewish abilities. Elsewhere Balfour speaks of the Jews as historically unique: "The position of the Jews is unique. For them race, religion and country are inter-related, as they are inter-related in the case of no other race, no other religion, and no other country on earth." ${ }^{44}$

Note (4) the idea that Christianity owes a debt to Judaism - a debt that it has shockingly failed to repay, and which should be repaid by supporting Jewish aspirations for a return to their ancient land. Again, this is a wellknown Christian Zionist trope. British Christian Zionists were deeply opposed to antisemitism and rallied in numbers to support Jews when they came under attack in Europe. Interestingly, they saw antisemitism as a European problem, a problem specifically of Catholic Europe. They used it as a stick with which to beat the Roman Catholic Church. It became a standard element of the anti-Catholicism of British Evangelicalism. Antipopery was fundamental to the English Protestant identity. When Balfour talks about "the Jewish problem" he is surely thinking specifically of the Russian pogroms of I88I-84, which happened when he was in his thirties. These roused enormous indignation in Britain and were the subject of large protest meetings. They led to a revival of Christian Zionism and to the Grand Old Man Shaftesbury's last hurrah for the Zionist cause. Balfour was also, doubtless, thinking of the Kishinev pogrom of 1903 , which again stirred widespread interest in Britain.

There is an irony here which might be lost on anyone but an Irishman. One of the people who did most to alert the world to the atrocities in Kishinev was the Irish nationalist and journalist, Michael Davitt. He visited the town and wrote an account that caused a sensation. ${ }^{45}$ In Steve

44 Balfour, "Introduction" to Sokolow, History of Zionism, I: Xxx.

45 See Colum Kenny, "Sinn Féin, Socialists and 'McSheeneys': Representations of Jews in Early Twentieth-Century Ireland,” Journal of Modern Jewish Studies (I4 Dec. 20I6): 198218. 
Zipperstein's opinion, Davitt was as influential as Bialik in stirring up the conscience of the world. ${ }^{46}$ Arthur Griffith, the founder of Sinn Féin, also wrote about later attacks on Jews. Irish nationalism quickly sensed an affinity to nascent Zionism, though this did not stop Irish Republicans from coming out with old-fashioned antisemitism, attacking Jews as capitalists, rack-renters, and factory owners who oppressed the Irish poor. These were "the wrong kind of Jews". ${ }^{47}$ The right sort were the Jewish nationalists who wanted to go off to Palestine and found their state. Davitt condemned the Limerick pogrom of 1904, but Griffith did not. Support for Zionism can go hand in hand with antisemitism. ${ }^{48}$ Balfour - "Bloody Balfour" as he was known in Ireland - stamped hard on Irish nationalism but had a soft-spot for Jewish nationalism. The inconsistency is revealing and suggests that in the case of the Jews he was led by the heart more than by the head. ${ }^{49}$

Note (5) that the Jews constitute a "race" and by implication should find their natural expression in a nation-state, a point which I argued earlier had been central to Christian Zionism since the seventeenth century, though it was also a commonplace of political philosophy in the late nineteenth and early twentieth century.

Finally, note (6) two absences from Balfour's statement. First, the absence of any reference to biblical prophecy. The contrast with Shaftes-

46 Steven J. Zipperstein, "Inside Kishinev's Pogrom: Hayyim Nahman Bialik, Michael Davitt, and the Burden of Truth", in The Individual in History: Essays in Honor of Jehudah Reinharz, ed. Y. ChaeRan Freeze, Sylvia Fuks, and Eugene Sheppard (Waltham, MA: Brandeis University Press, 2015), 365-83.

47 The phrase comes from Weizmann's account of his meeting with Balfour in Manchester in January I9o6; see n. 6 above. For a "riff" on this theme, see Clark, Allies for Armageddon, 123-44.

48 See Clark, Allies for Armageddon, I28-36. Weizmann, Trial and Error, 195-7, reports that in a conversation with Balfour at Carlton Gardens on I2 Dec. 19I4, Balfour expressed sympathy for some of the antisemitic views put to him by Cosima Wagner at Bayreuth, views expounded by Richard Wagner and Houston Stewart Chamberlain; Leonard Stein, The Balfour Declaration (London: Vallentine Mitchell, I96r), I54-6. Max Egremont, Balfour: A Life of Arthur James Balfour (London: Collins, I980), 263, suggests that Balfour was only "testing" Weizmann. If that is meant to suggest that Balfour did not to some extent subscribe to negative Jewish stereotypes (though he was emphatically not an antisemite like the Wagners or Chamberlain), then, to say the least, it is questionable. The fact is, as Weizmann himself admitted, some Jews were the wrong sort of Jews, i.e., Jews who did not support Zionism. Zionism has been deeply critical of the false consciousness - the Galut mentality - of many Jews.

49 Although Balfour would doubtless have rationalized this by arguing for Jewish exceptionalism; "Introduction" to Sokolow, History of Zionism, I: xxx. You cannot extrapolate from any other nationalist movement to Zionism, or vice versa. 
bury could hardly be starker. Shaftesbury was up to his neck in prophecy, and prophecy manifestly influenced his thinking about the Jews. But even he, when dealing with Palmerston, was shrewd enough to realise that prophetic arguments would cut no ice, and so he resorted (through gritted teeth) to Realpolitik. Maybe Balfour felt the same way. The House of Lords was hardly the place to give an impromptu Bible reading. But I think not. Nowhere else in Balfour's writings is there a hint that biblical prophecy was a factor in his pro-Zionist stance. But this too has antecedents in Christian Zionism. The dominant strand of Christian Zionism undoubtedly laid great store by biblical prophecies, but there was a version of it - humanitarian or ethical Christian Zionism - which argued that Christians had a moral duty, on Christian grounds, on the grounds of natural justice, to right the great wrongs that the Jewish people had suffered at Christian hands, and one way to do that was to support their return to Zion. Balfour fits comfortably into this.

The second absence is any reference to the conversion of the Jews. This as we saw was central to Christian Zionism, but there is not a shred of evidence that Balfour had any interest in bringing Jews to Christ. However, by Balfour's day this conversionist urge was waning in some forms of Christian Zionism. The consuming passion had become the Restoration itself. Lewis notes this trend and quotes as an example a remarkable letter from William Hechler written in 1898 to a friend in Jerusalem:

Of course, dear colleague, you look to the conversion of the Jews, but the times are changing rapidly, and it is important for us to look further and higher. We are now entering, thanks to the Zionist Movement, into Israel's Messianic age. Thus it is not a matter these days of opening all the doors of your churches to the Jews, but of opening the gates of their homeland, and of sustaining them in their work of clearing the land, and irrigating it, and bringing water to it. All this, dear colleague, is messianic work; all of this the breath of the Holy Spirit announces. But first, the dry bones must come to life, and draw together. ${ }^{50}$

This downplaying of conversion continues in American Christian Zionism today, though it is partly tactical, because the Israeli government will not tolerate foreign Christian proselytizing in Israel.

In her fine essay, "Biblical Prophecy, the Evangelical Movement, and the Restoration of the Jews to Palestine", Sarah Kochav writes: "The image of the Jew and the Holy Land, moulded by millenarian Evangelicals, was

50 Lewis, Origins ofChristian Zionism, 330. 
what remained for Lloyd George and his contemporaries, long after the concepts of eschatology had vanished. And when we remember this, we see how influential biblical prophecy and the Evangelical movement was in the Restoration of the Jews to Palestine." ${ }^{51}$ I think this gets it just about right, though I would be wary of implying, as I sense she may be doing, that the prophetic strand faded away, and was bound to fade away. We must be careful not to assume the onward and irreversible march of secularization. The new visibility of religion is a fact of our contemporary, twenty-first century world. Prophetic Christian Zionism has not faded away. It is alive and well and rampant in America. ${ }^{52}$

How can we tell what motivates any of us to do what we do, to make the choices we make? As Pascal memorably said, "The heart has its reasons which the reason knows not of", and as historians we would do well to remember this. Arthur Balfour was a complex character, hard to read. His reasons for backing Zionism may have been multiple. He may not have been fully aware of some of them himself. I have argued that his religious background and formation played a part. Certainly, the Balfour Declaration did not come out of the blue. It can be seen as the culmination of four hundred years of British Christian Zionism. It was a triumph as much for Christian Zionism as for Jewish Zionism. This centenary year of the Declaration offers an opportunity to reassess and critique ${ }^{53}$ the

5I Sarah Kochav, "Biblical Prophecy, the Evangelical Movement, and the Restoration of the Jews to Palestine, 1790-I860", Britain and the Holy Land 1800-1914: Papers Presented at the Warburg Institute, 8 February 1989: 2I, quoted in Lewis, Origins of Christian Zionism, I. Kochav did her doctoral thesis on "Britain and the Holy Land: Prophecy, the Evangelical Movement, and the Conversion and Restoration of the Jews, I790-I845" (Oxford University, 1989). The deeply secularist ethos of modern academic historiography serves modern academic historians ill when they come to analyse religious worldviews which are alien to their own. They cannot begin to understand how modern, often welleducated, successful people can be motivated by what to them are primitive ideas.

52 See the chilling account by Clark, Allies for Armageddon.

53 It is beyond the scope of the present paper to critique Christian Zionism. Suffice to say that, since Christian Zionism is a theology, that critique will be ineffective if it does not have a theological dimension. There is a startling ideological congruence of Prophetic Christian Zionism, Jewish Religious Zionism, and Jihadist Islam. The first two align closely on the restoration of the Jewish State, and the reason is simple: they are both drawing on the same biblical prophecies and promises, to which they apply the same literalist hermeneutic. The third, of course, is anti-Israel, and talks in lurid terms about obliterating Israel from the map, but this should not blind us to the fact that it displays precisely the same apocalyptic-eschatological mentality as the other two. The springs of its thought lie in classical Islamic eschatology which owes much to the Judaeo-Christian tradition. For a useful introduction see Bernard McGinn, John 
contribution of Christian Zionism to the founding, and ongoing history, of the State of Israel.

J. Collins, and Stephen J. Stein, eds., The Continuum History of Apocalypticism (New York and London: Continuum, 2003), esp. Said Amir Arjomand, "Islamic Apocalypticism in the Classical Period", 380-4I6, and Abbas Amanat, "The Resurgence of Apocalypticism in Modern Islam", 582-607.

(C) 2017, The Author(s). This is an Open Access article distributed under the terms of the Creative Commons Attribution License (CC-BY) 4.0 https://creativecommons.org/ licenses/by/4.o/, which permits unrestricted use, distribution, and reproduction in any medium, provided the original author and source are credited. 